\title{
In Situ Localization of Ribosomal Sites in Peckoltia and Ancistomus (Loricariidae: Hypostominae) from the Amazon Basin
}

\author{
Ananda Marques Pety, Adauto Lima Cardoso, Cleusa Yoshiko Nagamachi, ${ }^{1, *}$ \\ Julio Cesar Pieczarka, ${ }^{1, *}$ Leandro Melo de Sousa, and Renata Coelho Rodrigues Noronha ${ }^{1}$
}

\begin{abstract}
Loricariidae is a diverse group of fish from the neotropical region, occupying a wide variety of freshwater environments. Cytogenetic data have brought important insights into Loricariidae diversity because they help validate undescribed species as well as our understanding of inter- and intraspecific diversity. However, conventional cytogenetic approaches are limited in their ability to detect variability in some lineages, as seen in the Peckoltia clade, owing to their apparent conserved karyotype. Thus, the aim of this work was to map 5S and $18 \mathrm{~S}$ ribosomal (rDNA) sites in five species of Peckoltia and one species of Ancistomus from the Amazon basin, and discusses the mechanisms of organization and diversification of these clusters. The species analyzed were found to have $2 \mathrm{n}=52$ and share $\mathrm{KF}=38 \mathrm{~m}-\mathrm{sm}+14 \mathrm{st}-\mathrm{a}$ chromosomes, except Peckoltia vittata with $\mathrm{KF}=34 \mathrm{~m}-\mathrm{sm}+$ 18st-a. Extensive variations in the number and location of 5S and 18S rDNA sites were observed among species. These data indicate that inversions are not the most important events in karyotype evolution in this group, and should prove useful in identifying the species studied here. In addition to inversions, transpositions are important evolutionary events that are involved at least in rDNA clusters spreading in Peckoltia and probably in other species of Hypostominae.
\end{abstract}

Keywords: repetitive DNA, multigene family, syntenic genes, ornamental Amazon fish

\section{Introduction}

L ORICARIIDAE IS A DIVERSE GROUP of fish (951 valid species) from the neotropical region, occupying a wide variety of freshwater environments. ${ }^{1-3}$ This family is composed of six subfamilies, with Hypostominae being the most species-rich and harboring the largest number of karyotyped species. ${ }^{4}$ Hypostominae, in turn, is composed of seven clades (Chaetostoma, Pseudancistrus, Lithoxus, Pseudancistrus, Acanthicus, Hemiancistrus, and Pekoltia) and two tribes (Ancistrini and Hypostomini). ${ }^{5}$ Data for Hypostomini and Ancistrini, the most studied in cytogenetic terms, indicate a wide divergence of karyotype among Hypostomini $(2 n=64-80)$ and Ancistrini $(2 \mathrm{n}=34-54) .^{6-9}$

Cytogenetic data have provided important insights into Loricariidae diversity because they validate undescribed species and aid understanding of inter- and intraspecific diversity. ${ }^{10-12}$ However, among Peckoltia species, the determination of number of chromosomes alone is not useful for resolving these issues, because most species exhibit a stable $2 n$ karyotype. ${ }^{10-13}$ Thus, the use of other chromosomal markers is necessary to clarify the genomic organization of these species and understand their diversity.

The physical mapping of repetitive DNAs has been widely used as an important tool in the study of taxonomic and evolutionary problems in fish, as well as to understand the processes of genomic organization and diversification. ${ }^{14-16}$ According to Kidwell, ${ }^{17}$ such sequences may also be involved in chromosomal rearrangements, such as deletions, duplications, inversions, and translocations, being responsible for karyotypic variations observed in many groups. In this way, the repetitive DNAs constitute an important chromosomal marker, being useful for cytogenetic studies. Cytogenetic studies in Loricariidae have been performed with probes of $18 \mathrm{~S}$ and $5 \mathrm{~S}$

\footnotetext{
${ }^{1}$ Laboratório de Citogenética, Centro de Estudos Avançados da Biodiversidade, Instituto de Ciências Biológicas, Universidade Federal do Pará, Belém, Para, Brazil.

${ }^{2}$ Laboratório Genômica Integrativa, Departamento de Morfologia, Instituto de Biociências, Universidade Estadual Paulista, Botucatu, Brazil.

${ }^{3}$ Faculdade de Ciências Biológicas, Universidade Federal do Pará, Altamira, Para, Brazil.

*CNPq Researcher.
} 
Table 1. Compilation of Chromosome Data of PECKOLTIA SPECIES

\begin{tabular}{|c|c|c|c|}
\hline Species & $2 n$ & $K F$ & Reference \\
\hline Peckoltia vittata & 52 & $36 \mathrm{~m}+\mathrm{sm}, 14 \mathrm{st}, 2 \mathrm{a}$ & Souza et al. ${ }^{27}$ \\
\hline Peckoltia sp.1 & 52 & $\begin{array}{c}44 \mathrm{~m}+\mathrm{sm}, 6 \mathrm{st}, \\
2 \mathrm{a} ;+1 \mathrm{~B}\end{array}$ & Souza et al. $^{27}$ \\
\hline Peckoltia sp. 2 & 52 & $32 \mathrm{~m}+\mathrm{sm}, 18 \mathrm{st}, 2 \mathrm{a}$ & Souza et al. $^{27}$ \\
\hline Peckoltia cavatica & 52 & $38 \mathrm{~m}+\mathrm{sm}, 14 \mathrm{st}$ & Present work \\
\hline Peckoltia feldbergae & 52 & $38 \mathrm{~m}+\mathrm{sm}, 14 \mathrm{st}$ & Present work \\
\hline Peckoltia multispinis & 52 & $28 \mathrm{~m}+\mathrm{sm}, 24 \mathrm{st}$ & Present work \\
\hline Peckoltia oligospila & 52 & $38 \mathrm{~m}+\mathrm{sm}, 14 \mathrm{st}$ & Present work \\
\hline Peckoltia sabaji & 52 & $38 \mathrm{~m}+\mathrm{sm}, 14 \mathrm{st}$ & Present work \\
\hline Peckoltia vittata & 52 & $32 \mathrm{~m}+\mathrm{sm}, 18 \mathrm{st}, 2 \mathrm{a}$ & Present work \\
\hline
\end{tabular}

rDNAs in several Loricariidae genera: Ancistrus, ${ }^{6,9}$ Harttia, ${ }^{18-20}$ Hypancistrus, ${ }^{11,12}$ Hypostomus, ${ }^{7,21-23}$ among others. Such studies have shown great variation both in the number of these sites and in their locations.

Peckoltia is a genus of the Peckoltia clade with 18 recognized species distributed in the Amazon and Orinoco basins and Guiana shield, several of which are exploited in the ornamental trade. ${ }^{24-26}$ Classical cytogenetic data are only available for Peckoltia vittata from the Xingu River and Peckoltia sp. 1 and Peckoltia sp. 2 from the Jari River, both with 52 chromosomes and divergences in karyotype formula (Table 1). ${ }^{27}$ The genus Peckoltia itself is a historically problematic taxon that is often confused with Hemiancistrus. $^{2,24}$ According to Lujan et al., ${ }^{5}$ Ancistomus is a valid genus for the Peckoltia clade, including "Peckoltia" feldbergae in this genus. Therefore, it is necessary to identify other species and use other chromosomal markers to understand the process of karyotype diversification in this genus. Thus, the aims of this work were to map the minor and major rDNA sites in the karyotypes of five species of Peckoltia plus one species of Ancistomus from the Amazon basin and dis- cuss the mechanisms of organization and diversification of these clusters.

\section{Materials and Methods}

In this study, we analyzed samples from one species of the genus Ancistomus and five species of the genus Peckoltia (Figs. 1 and 2). Sample collection was authorized by Instituto Chico Mendes de Conservação da Biodiversidade (ICMBio) and Secretaria de Estado de Meio Ambiente do Pará (SEMAPA); permit 020/2005. Animals were anesthetized with eugenol and chromosomes were obtained as described by Bertollo et $a$ l. $^{28}$ Nucleolar organizer regions (NORs) were detected using $\mathrm{AgNO}_{3}$, as described by Howell and Black, ${ }^{29}$ and fluorescent in situ hybridization (FISH) was conducted following the method of Martins and Galetti ${ }^{30}$ using probes for $5 \mathrm{~S}$ and $18 \mathrm{~S}$ rDNA, labeled with biotin or digoxigenin using nick translation and detected using avidin-Cy3 or antidigoxigenin-FITC, respectively. The karyotypes were classified as described by Levan et al. ${ }^{31}$

\section{Results}

The six species analyzed in this study were found to have a diploid number (2n) of 52 chromosomes. Moreover, most species possessed 38 meta-submetacentric and 14 subteloacrocentric chromosomes, except $P$. vittata, which had 34 meta-submetacentric and 18 subteloacrocentric chromosomes (Fig. 2).

Impregnation of $\mathrm{NORs}$ with $\mathrm{AgNO}_{3}$ indicated a single NOR in $A$. feldbergae in the terminal region of $20 \mathrm{q}$, in Peckoltia cavatica in the terminal region of $9 \mathrm{q}$, in Peckoltia multispinis in the terminal region of the $5 \mathrm{q}$ homologue, and in $P$. vittata in the terminal region of $10 \mathrm{q}$, whereas multiple NORs were indicated in Peckoltia oligospila for each homologous terminal region in $10 \mathrm{q}$ and $20 \mathrm{q}$, and in Peckoltia sabaji in the terminal regions of $7 q$ and $20 q$ (Fig. 2).

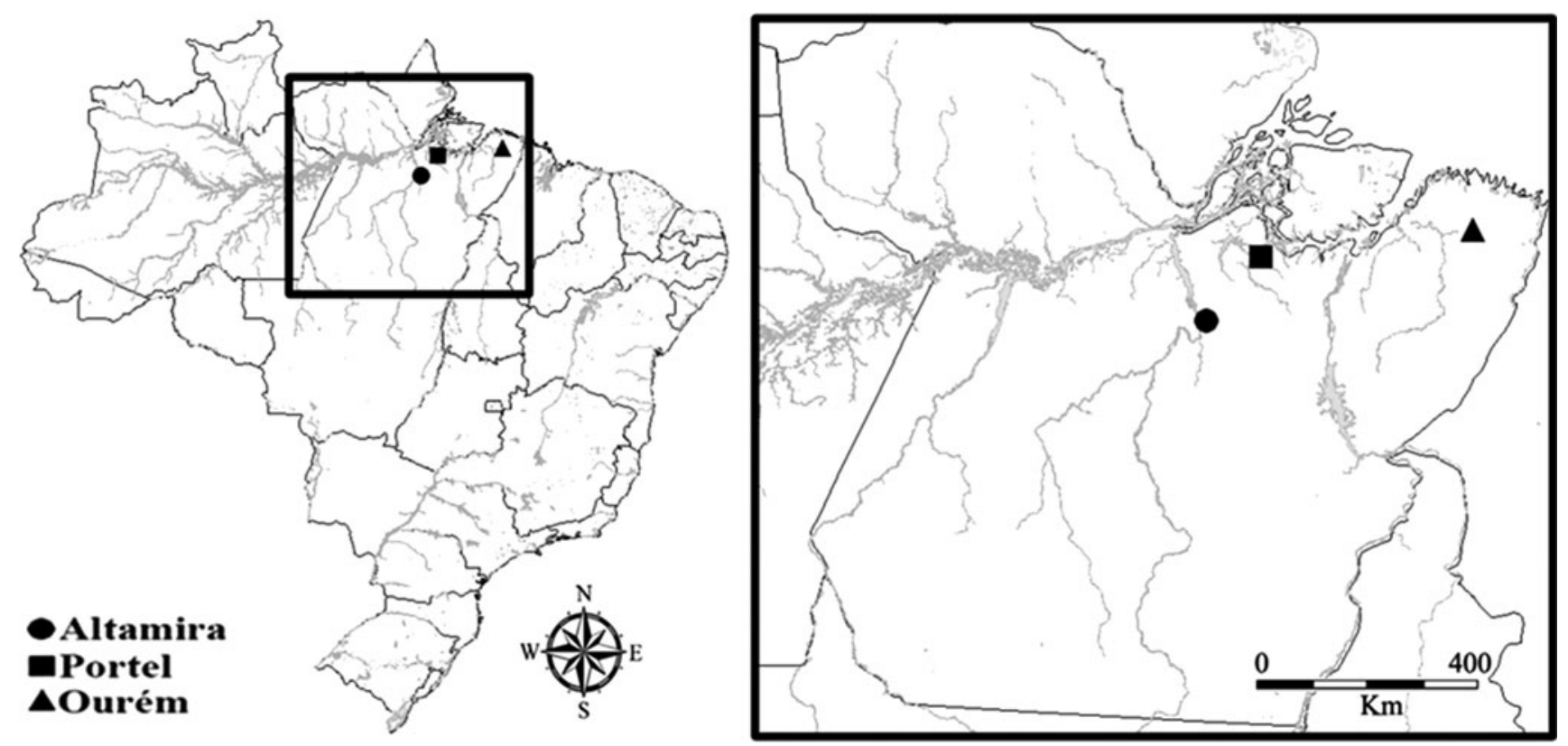

FIG. 1. Localities of the samples analyzed in this study. 


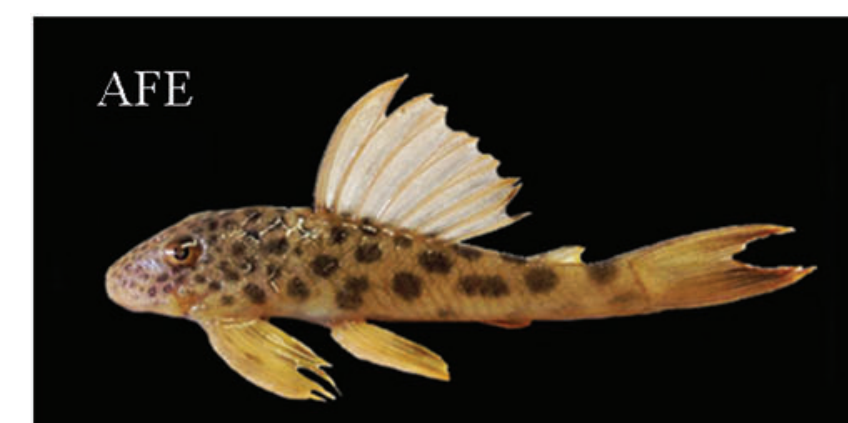

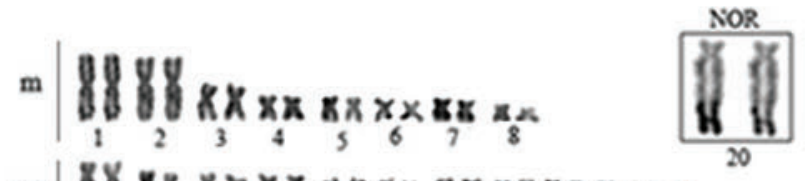

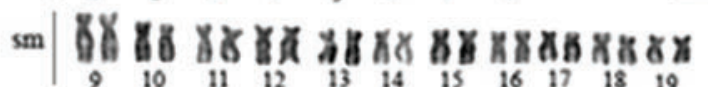

st |

$\begin{array}{lllllll}20 & 21 & 22 & 23 & 24 & 25 & 26\end{array}$

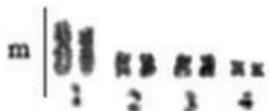

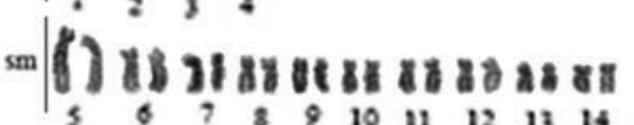

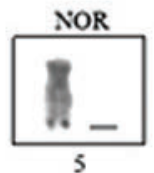

PMU

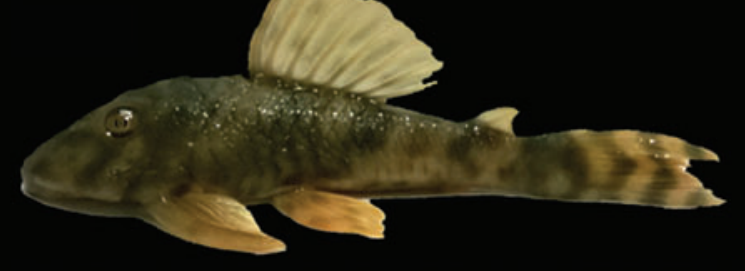

POL

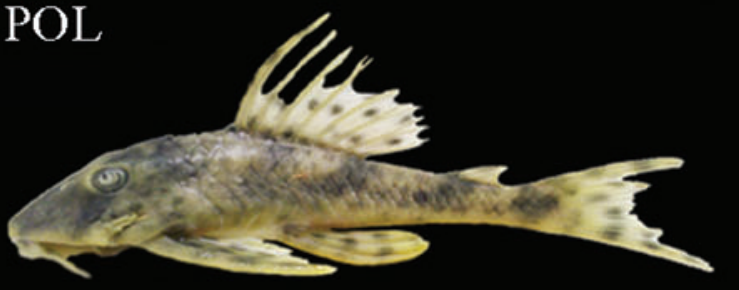

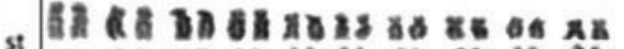

is 16 is 17 is 29 21 $22 \quad 23 \quad 34$

in as

2526

$\mathrm{m} \mid \begin{gathered}8 \\ 1\end{gathered}$

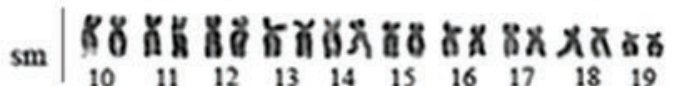

st |

m

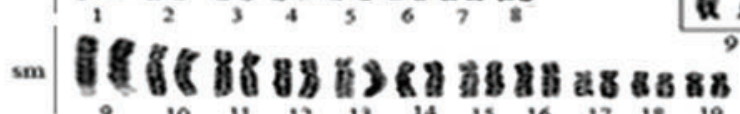

PCA

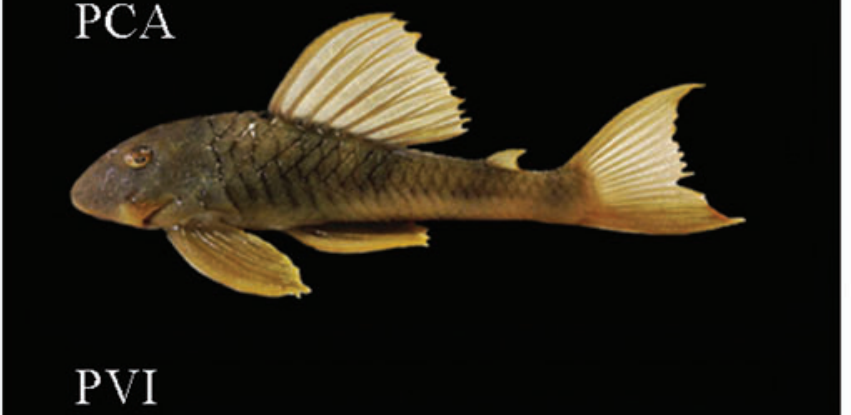

st

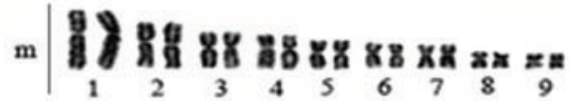

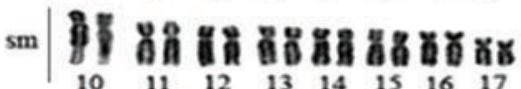
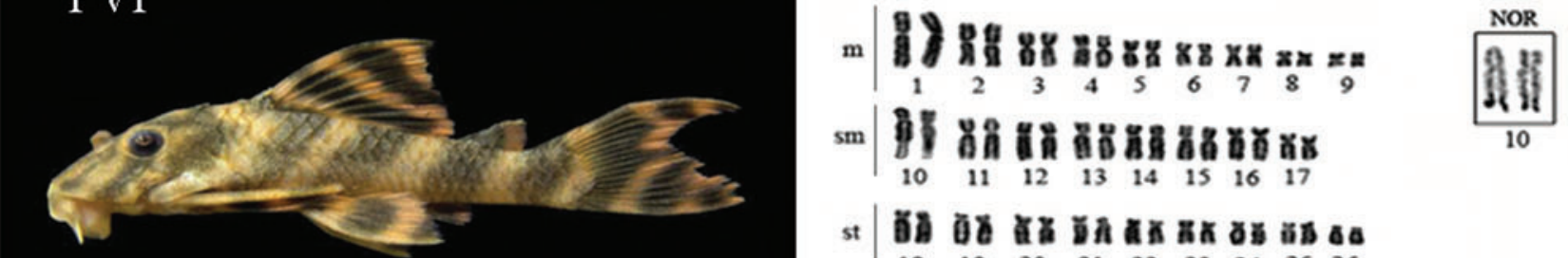

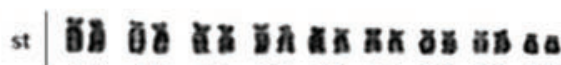

$\begin{array}{lllllllll}18 & 19 & 20 & 21 & 22 & 23 & 24 & 25 & 26\end{array}$

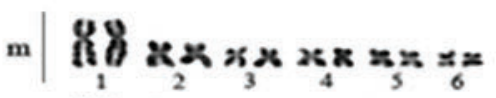
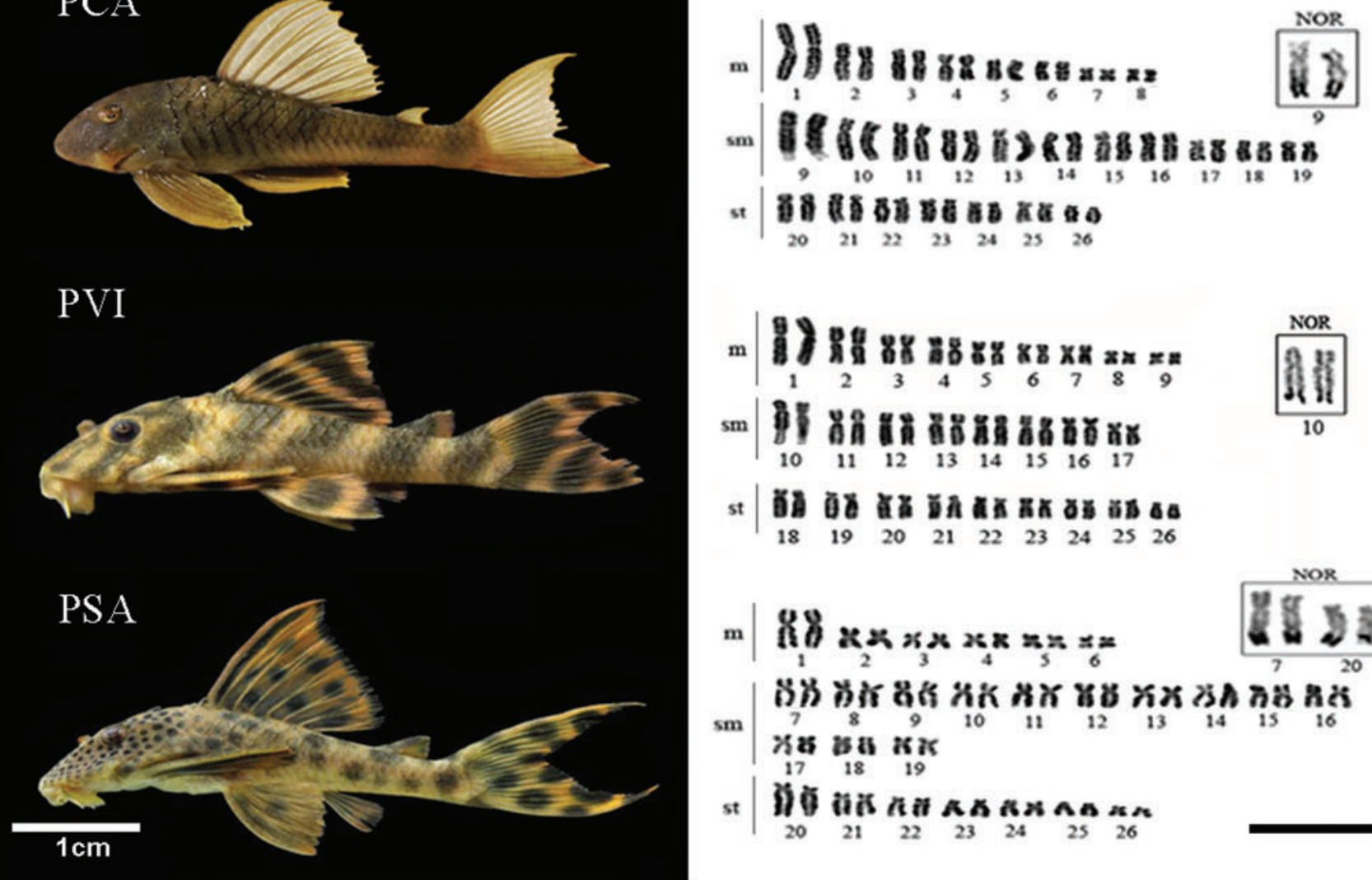

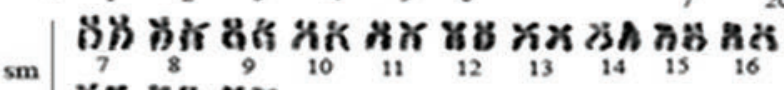

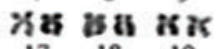

st |⿱㇒冋幺乌

FIG. 2. Species of Ancistomus and Peckoltia analyzed in this work (left, scale bar $=1 \mathrm{~cm}$ ) and their, respectively, karyotypes (right, scale bar $=10 \mu \mathrm{m})$. AFE, A. feldbergae; PMU, P. multispinis; POL, P. oligospila; PCA, P. cavatica; PVI, $P$. vittata; PSA, P. sabaji. Color images available online at www.liebertpub.com/zeb 


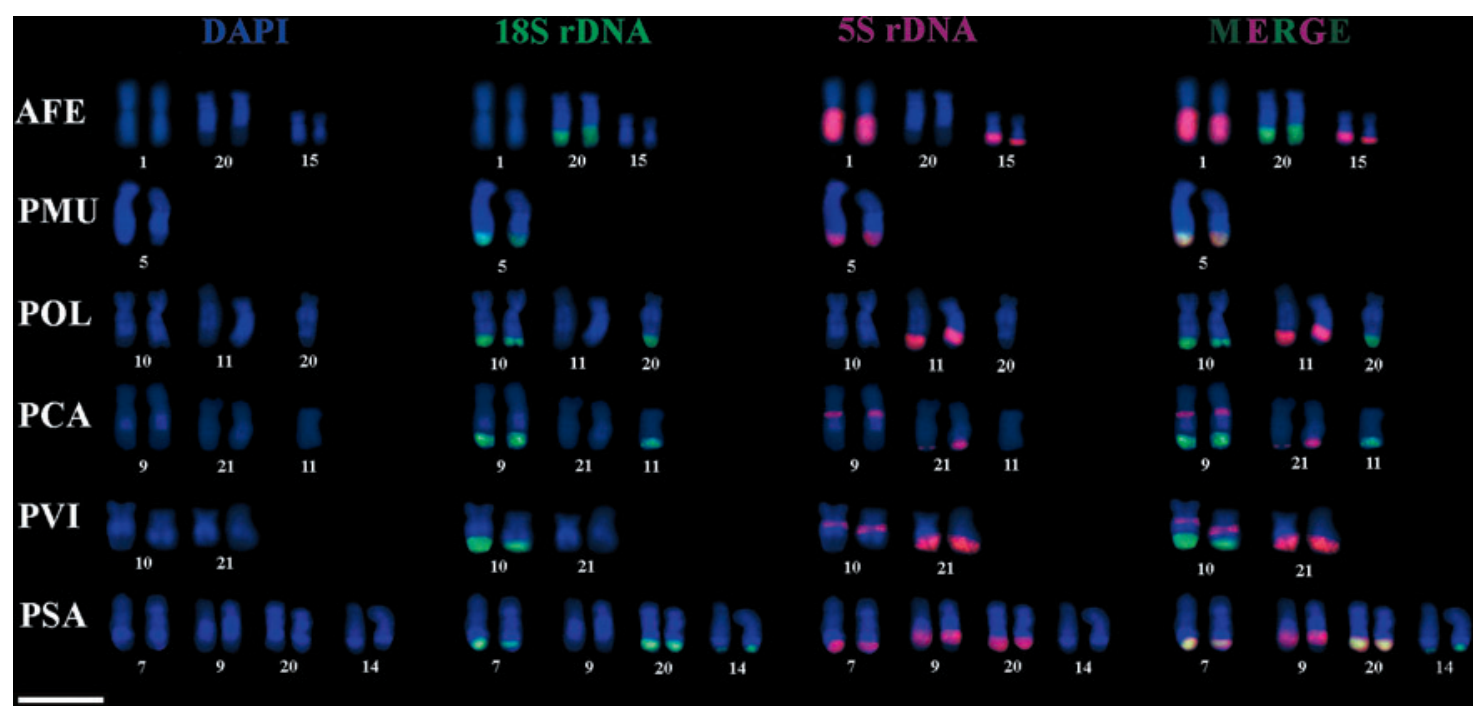

FIG. 3. Chromosomal mapping of $18 \mathrm{~S}$ (green) and 5S (red) rDNA in Ancistomus and Peckoltia species. Scale bar $=10$ $\mu \mathrm{m}$. AFE, A. feldbergae; PMU, P. multispinis; POL, P. oligospila; PCA, P. cavatica; PVI, P. vittata; PSA, P. sabaji. Color images available online at www.liebertpub.com/zeb

The location of $18 \mathrm{~S}$ and $5 \mathrm{~S}$ rDNA sites was divergent among the six species (Fig. 3). In P. multispinis, $18 \mathrm{~S}$ and $5 \mathrm{~S}$ rDNA were colocalized in 5q; in A. feldbergae, $18 \mathrm{~S}$ rDNA sites were in 20q and 5S rDNA sites were in 1q and 15q; in $P$. oligospila, 18S rDNA sites were in 10q and 20q and 5S rDNA sites were in $11 \mathrm{q}$; in $P$. cavativa, $18 \mathrm{~S}$ rDNA sites were in $9 \mathrm{q}$ and $11 \mathrm{q}$ and $5 \mathrm{~S}$ rDNA sites were in $9 \mathrm{q}$ and $21 \mathrm{q}$; in $P$. vitatta, $18 \mathrm{~S}$ rDNA sites were in 10q and 5S rDNA sites were in 10q and $21 \mathrm{q}$; in $P$. sabaji, $18 \mathrm{~S}$ rDNA sites were in $7 \mathrm{q}, 14 \mathrm{q}$, and 20q, and 5S rDNA sites were in 7q, 9q, and 20q. Most rDNA sites had a terminal location, except one $5 \mathrm{~S}$ rDNA site, which was in the proximal region in $P$. cavatica and $P$. vitatta. Moreover, the sites of the two classes of rDNA were in different chromosomes in A. feldbergae and $P$. oligospila. However, there were also $18 \mathrm{~S}$ and 5S rDNA sites in the same chromosome, such as in $P$. cavatica and $P$. vitatta, and some were even colocalized, as was the case in $P$. multispinis and $P$. sabaji. In addition, intraspecific heteromorphisms in the size of rDNA clusters were observed in the six species.

\section{Discussion}

The six species analyzed in this study exhibited a $2 n=52$ karyotype, which is purported to be a synapomorphy of Ancistrini $^{32}$ and is shared with congeneric species (Table 1). ${ }^{27}$ However, there are some divergences in chromosome morphologies, which must result from inversions, mainly pericentric, that are inversions that have been identified as the main source of karyotype evolution in Ancistrini. ${ }^{33}$ However, inversions are not the only events involved in chromosome reorganization in Ancistrini, Robertsonian fusion events and diploid reduction are sources of diversification in the chromosome evolution of the clade species (Fig. 4). ${ }^{6,9,10-13,34-36}$ Centromeric reposition could also explain this variation, since this mechanism can change chromosome morphology without modifying number of chromosomes. ${ }^{32,35,37}$

A small difference in karyotype formula was also detected among the $P$. vittata analyzed in this study and those described by Souza et al. ${ }^{27}$ despite both samples being from Xingu River. It is possible that a chromosome inversion occurred during sympatric divergence of the two karyomorphs. However, the combination of gametes in chromosomes of polymorphic populations may lead to a difference in the karyotype. ${ }^{38}$

FISH mapping and Ag-NOR analysis revealed the occurrence of inactive sites of $18 \mathrm{~S}$ rDNA in $P$. cavatica, $P$. multispinis, and P. sabaji. Similarly, the mapping of 5S rDNA sequences revealed a dynamic organization of these sequences among species: whereas $P$. multispinis and $P$. oligospila had a single site, the other species had two or three sites. $8,13,34,35$ Moreover, we identified cases wherein the minor (5S) and major (18S) sites of rDNA were in different chromosome pairs and cases wherein these two classes of rDNA were syntenic and even colocalized, as observed in Neopleocostominae, Hypoptopomatinae, ${ }^{39}$ Loricarininae, ${ }^{4}$ Hypostominae, ${ }^{6,9,21,38}$ and the Trichomycteridae family. ${ }^{39}$ This type of arrangement of these sequences is not common in fish species, since it tends to favor unequal crossing over events and gene conversion. ${ }^{38}$ Despite this, colocalization of $5 \mathrm{~S}$ and $18 \mathrm{~S}$ rDNA was observed in some species of Loricariidae, including Ancistrini. ${ }^{6,9,35}$ However, nonsyntenic organization of minor and major rDNA clusters is the most frequently observed organization in species of this tribe. According to Zienmiczak, ${ }^{39}$ the synteny between the two classes of rDNA on a single chromosome pair is a plesiomorphic condition for Loricariidae. As proposed by Mariotto, ${ }^{6}$ the ancestral karyotype in the Ancistrus genus is similar to that presented by Ancistrus claro (Fig. 4), which has $2 \mathrm{n}=54$ chromosomes, a high fundamental number, and one chromosome pair with syntenic $5 \mathrm{~S}$ and $18 \mathrm{~S}$ rDNA sites. For the same characteristics, except for $2 \mathrm{n}$, we can observe in $P$. cavatica and $P$. vittata the presence of a $5 \mathrm{~S}$ rDNA site in the interstitial region in the same chromosome with the single NOR, which may be a primitive remnant condition for the Peckoltia clade, as found in Hypancistrus cf. debilittera ${ }^{12}$ and Panaqolus sp., ${ }^{13}$ belonging to the same clade, and in the Ancistrus ${ }^{6,9,35,40}$ genus that is of the same subfamily Hypostominae. ${ }^{5}$ 


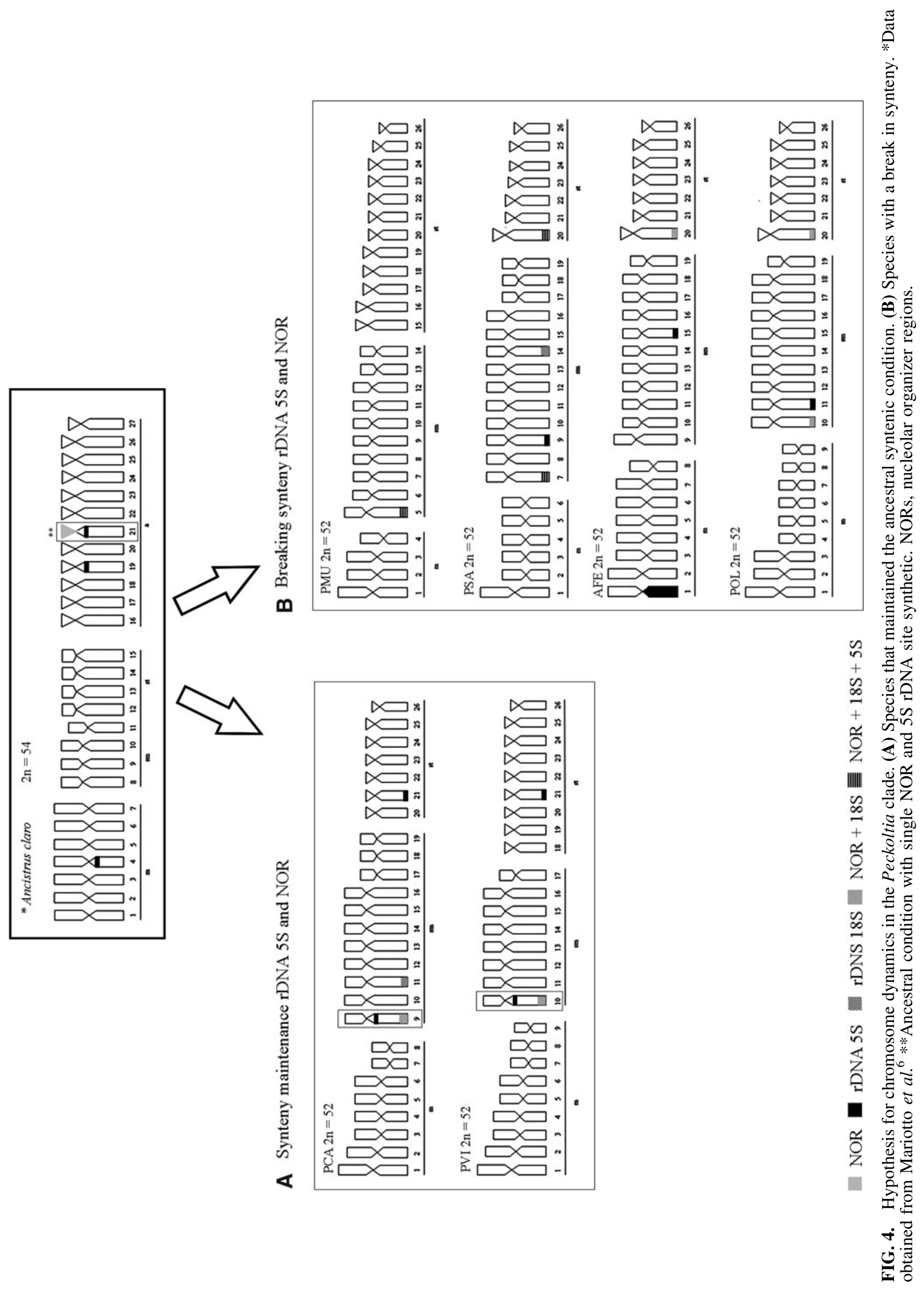


Data relating to organization of rDNA clusters indicate that other types of chromosome rearrangements in addition to inversions should have occurred during karyotype divergence of these species. Chromosome translocations, for example, could explain the difference in chromosome location of rDNA sites. These events were presumably mediated by transposition mechanisms, which have been documented to apply to these types of sequences owing to the common presence of transposable elements in association with rDNAs. ${ }^{41,42}$ Retroposition events, for example, could explain the difference in the number of rDNA sites among species, since these mechanisms can produce new copies. ${ }^{43}$ In contrast, it is possible that degeneration of rDNA sites took place in species with a reduced number of these sites. Moreover, intraspecific size heteromorphisms of rDNA clusters were observed among the six species. These could be explained by duplication events mediated by unequal crossing over, events that are commonly described in vertebrate species. ${ }^{44}$

The present data on $2 \mathrm{n}, \mathrm{KF}$, and location of rDNA clusters suggest that the karyotype of Peckoltia, as well as that of other Hypostominae species, is not stable. Thus, inversions may not be the most important mechanism of karyotype rearrangement in this group, as previously supposed. In turn, transpositions and duplications also seem to be important evolutionary events, involved at least in rDNA clusters spreading in this group. Moreover, the data set generated here could provide taxonomic markers and thus should prove very useful in identifying Peckoltia species. They could also provide evidence for a postzygotic reproductive isolation mechanism among sympatric species from the Xingu River, as suggested for Scobinancistrus aureatus and Scobinancistrus pariolispos. ${ }^{10}$

\section{Acknowledgments}

This study is part of master dissertation of A.M.P. who was a recipient of a CAPES Scholarship in Neurosciences and Cell Biology, UFPA. The authors are grateful to members of the team of cytogenetics laboratory UFPA in the field work and chromosomal preparations and to MSc. Jorge Rissino, MSc. Shirley Nascimento, and Maria da Conceição for assistance in laboratory work. This research was supported by Conselho Nacional de Desenvolvimento Científico e Tecnológico $(\mathrm{CNPq})$ through the Edital Universal (proc. 475013/2012-3) and Coordenação de Aperfeiçoamento de Pessoal de Nível Superior (CAPES) through the Edital 047/2012 PRÓ-AMAZÔNIA: Biodiversidade e Sustentabilidade on a project coordinated by C.Y.N.; by FAPESPA (Pará Foundation for Supporting Science) through the National Excellence on Research Program (PRONEX, TO 011/2008) and Banco Nacional de Desenvolvimento Econômico e Social-BNDES (Operação 2.318.698.0001) on a project coordinated by J.C.P. C.Y.N. (308428/2013-7) and J.C.P. (308401/ 2013-1) are grateful to CNPq for Productivity Grants. We also thank the Instituto Chico Mendes de Conservação da Biodiversidade (ICMBio) for the collection permit 020/2005 (Registration: 207419). The authors thank Projeto Arapaima Ltda (Pará) for help with field sampling, Cesar Martins UNESPBotucatu for primers for cytogenetic probes, and C.Y.N. and J.C.P. are both CNPq researchers.

\section{Disclosure Statement}

No competing financial interests exist.

\section{References}

1. Isbrücker IJH: Classification and Catalogue of the Mailed Loricariidae (Pisces, Siluriformes). (Verslagenen en technische Gegevens). Universiteit van Amsterdam, Amsterdam, 1980.

2. Armbruster JW. Phylogenetic relationships of the suckermouth armoured catfishes Loricariidae with emphasis on the Hypostominae and the Ancistrinae. Zool J Linn Soc 2004; 141:1-80.

3. Eschmeyer WN, Fong JD. Catolog of fishes. California Academy of Sciences 2017. Available at http://research archive.calacademy.org/research/ichthyology/catalog/Species ByFamily.asp. Accessed August 8, 2017.

4. Kavalco KF, Pazza R, Bertollo LAC, Moreira-Filho O. Karyotypic diversity and evolution of Loricariidae (Pisces, Siluriformes). Heredity (Edinb) 2005;94:180-186.

5. Lujan NK, Armbruster JW, Lovejoy NR, López-Fernández H. Multilocus molecular phylogeny of the suckermouth armored catfishes (Siluriformes: Loricariidae) with a focus on subfamily Hypostominae. Mol Phylogenet Evol 2015; 82:269-288.

6. Mariotto S, Centofante L, Vicari MR, Artoni RF, MoreiraFilho O. Chromosomal diversification in ribosomal DNA sites in Ancistrus Kner, 1854 (Loricariidae, Ancistrini) from three hydrographic basins of Mato Grosso, Brazil. Comp Cytogent 2011;5:289-300.

7. Traldi JB, Vicari MR, Blanco DR, Martinez JF, Artoni RF, Moreira-Filho O. First karyotype description of Hypostomus iheringii (Regan, 1908): a case of heterochromatic polymorphism. Comp Cytogent 2012;6:115-125.

8. Bueno V, Venere PC, Konerat JT, Zawadzki CH, Vicari MR, Margarido VP. Physical Mapping of the 5S and 18S rDNA in ten species of Hypostomus Lacépède 1803 (Siluriformes: Loricariidae): evolutionary tendencies in the genus. ScientificWorldJournal 2014;2014: Article ID 943825, 8 pages.

9. Favarato RM, Silva M, Oliveira RR, Artoni RF, Feldberg E, Matoso DA. Cytogenetic diversity and the evolutionary dynamics of rDNA genes and telomeric sequences in the Ancistrus genus (Loricariidae: Ancistrini). Zebrafish 2016; 13:103-111.

10. Cardoso AL, Sales KAH, Nagamachi CY, Pieczarka JC, Noronha RCR. Comparative cytogenetics of two species of genus Scobinancistrus (Siluriformes, Loricariidae, Ancistrini) from the Xingu River, Brazil. Comp Cytogenet 2013; 7:43-41.

11. Cardoso AL, Carvalho HL, Benathar TCM, Serrão SMG, Nagamachi CY, Pieczarka JC, et al. Integrated cytogenetic and mitochondrial DNA analyses indicate that two different phenotypes of Hypancistrus (L066 and L333) belong to the same species. Zebrafish 2016;13:209-216.

12. Silva M, Ribeiro ED, Matoso DA, Sousa LM, Hrbek T, PyDaniel LR, et al. Chromosomal polymorphism in two species of Hypancistrus (Siluriformes: Loricariidae): an integrative approach for understanding their biodiversity. Genetica 2014;142:127-139.

13. Ayres-Alves T, Cardoso Al, Nagamachi CN, De Sousa LM, Pieczarka JC, Noronha RCR. Karyotypic evolution and chromosomal organization of repetitive DNA sequences in species of Panaque, Panaqolus, and Scobinancistrus (Siluriformes and Loricariidae) from the Amazon basin. Zebrafish 2017;14:251-260.

14. Kazazian HH. Mobile elements: drivers of genome evolution. Science 2004;303:1626-1632.

15. Martins C, Wasko AP: Organization and evolution of $5 \mathrm{~S}$ ribosomal DNA in the fish genome. In: Focus on Genome 
Research. Williams CR (ed), pp. 289-318, Nova Science Publishers, Hauppauge, NY, 2004.

16. Biémont C, Vieira C. Junk DNA as an evolutionary force. Nature 2006;443:521-524.

17. Kidwell MG. Transposable elements and the evolution of genome size in eukaryotes. Genetica 2002;115:49-63.

18. Centofante L, Bertollo LAC, Moreira-Filho O. Cytogenetic characterization and description of an $\mathrm{XX} / \mathrm{XY}_{1} \mathrm{Y}_{2}$ sex chromosome system in catfish Harttia carvalhoi (Siluriformes, Loricariidae). Cytogenet Genome Res 2006;12: 320-324.

19. Blanco DR, Vicari MR, Lui RL, Artoni RF, Almeida MC, Traldi JB, et al. Origin of the $\mathrm{X}_{1} \mathrm{X}_{1} \mathrm{X}_{2} \mathrm{X}_{2} / \mathrm{X}_{1} \mathrm{X}_{2} \mathrm{Y}$ sex chromosome system of Harttia punctata (Siluriformes, Loricariidae) inferred from chromosome painting and FISH with ribosomal DNA markers. Genetica 2014;142:119-126.

20. Blanco DR, Vicari MR, Lui RL, Traldi JB, Bueno V, Martinez JF, et al. Karyotype diversity and evolutionary trends in armored catfish of the genus Hartia (Siluriformes: Loricariidae). Zebrafish 2017;14:169-176.

21. Pansonato-Alves JC, Serrano EA, Utsunomia R, Scacchetti PC, Oliveira C, Foresti C. Mapping five repetitive DNA classes in sympatric species of Hypostomus (Teleostei: Siluriformes: Loricariidae): analysis of chromosomal variability. Rev Fish Biol Fish 2013;23:477-489.

22. Traldi JB, Blanco DR, Vicari MR, Martinez JF, Lui RL, Barros AV, et al. Chromosomal diversity in Hypostomus (Siluriformes, Loricariidae) with emphasis on physical mapping of $18 \mathrm{~S}$ and 5S rDNA sites. Genet Mol Res 2013;12: 463-471.

23. Rubert M, da Rosa R, Zawadzki CH, Mariotto S, MoreiraFilho O, Giuliano-Caetano L. Chromosome mapping of $18 \mathrm{~S}$ ribosomal RNA genes in eleven Hypostomus species (Siluriformes, Loricariidae): diversity analysis of the sites. Zebrafish 2016;13:360-368.

24. Armbruster JW. The genus Peckoltia with the description of two new species and a reanalysis of the phylogeny of the genera of the Hypostominae (Siluriformes: Loricariidae). Zool J Linn Soc 2008;1822:1-76.

25. Armbruster JW, Werneke DC, Tan M. Three new species of saddled loricariid catfishes, and a review of Hemiancistrus, Peckoltia, and allied genera (Siluriformes). Zool J Linn Soc 2015;480:97-123.

26. De Oliveira RR, Py-Daniel LR, Zuanon J, Rocha MS. A new species of ornamental catfish genus Peckoltia (Siluriformes: Loricariidae) form Xingu Basin, Brazilian Amazon. Copeia 2012;3:547-553.

27. Souza ACP, Nagamachi CY, Milhomem SSR, Feldberg E, Pieczarka JC. Cytogenetics analysis in catfish species of the genus Peckoltia Miranda Ribeiro, 1912 (Teleostei: Siluriformes: Loricariidae). Comp Cytogenet 2009;3:103-109.

28. Bertollo LAC, Takashi CS, Moreira-Filho O. Cytotaxonomic considerations on Hoplias lacerdae (Pisces, Erythrinidae). Braz J Genet 1972;2:103-120.

29. Howell WM, Black DA. Controlled silver-staining of nucleolus organizer regions with a protective colloidal developer: a 1-step method. Experientia 1980;36:1014-1015.

30. Martins C, Galetti PM. Chromosome localization of 5S rDNA genes in Leporinus fish (Anostomidae, Characiformes). Chromosome Res 1999;7:363-367.

31. Levan A, Fredga K, Sandberg AA. Nomenclature for centromeric position on chromosomes. Hereditas 1964;52: 201-220.
32. Artoni RF, Bertollo LAC. Trends in the karyotype evolution in the Loricariidae fish (Siluriformes). Hereditas 2001; 134:201-210.

33. Alves AL, Oliveira C, Foresti F. Karyotype variability in eight species of the subfamilies Loricariinae and Ancistrinae (Teleostei, Siluriformes, Loricariidae). Caryologia 2003;56:57-63.

34. de Oliveira RR, Souza IL, Venere PC. Karyotype description of three species of Loricariidae (Siluriformes) and occurrence of the ZZ/ZW sexual system in Hemiancistrus spiloma Cardoso \& Lucinda, 2003. Neotrop Ichthyol 2006; 4:93-97.

35. Prizon AC, Borin-Carvalho LA, Bruschi DP, Ribeiro MO, Barbosa LM, Ferreira GEB, et al. Cytogenetic data on Ancistrus sp. (Siluriformes, Loricariidae) of the Paraguay River basin (MS) sheds light on intrageneric karyotype diversification. Comp Cytogen 2016;10:625-636.

36. Rocchi M, Archidiacono N, Schempp W, Capozzi O, Stanyon R. Centromere repositioning in mammals. Heredity 2012;108:59-67.

37. Montefalcone G, Tempesta S, Rocchi M, Archidiacono N. Centromere repositioning. Genome Res 1999;9:1184-1188.

38. Rosa KO, Ziemniczak K, de Barros AV, Nogaroto V, Almeida MC, Cestari MM, et al. Numeric and structural chromosome polymorphism in Rineloricaria lima (Siluriformes: Loricaridae) fusion points carrying $5 \mathrm{~S}$ rDNA or telomere sequence vestiges. Rev Fish Biol Fisheries 2012; 22:739-749.

39. Ziemniczak K, Barros AV, Rosa KO, Nogaroto V, Almeida MC, Cestari MM, et al. Comparative cytogenetics of Loricariidae (Actinopterygii: Siluriformes): emphasis in Neoplecostominae and Hypoptopomatinae. Ital J Zool 2012;79:1-10.

40. Ribeiro MO, Noleto RB, Lorscheider CA, Porto FE, Prizon AC, Zawadzki $\mathrm{CH}$, et al. Cytogenetic description of Ancistrus abilhoai (Siluriformes: Loricariidae) from Iguaçu River basin, southern Brazil. Genet Mol Res 2015;14: 4051-4057.

41. Dover GA. Molecular drive in multigene families: how biological novelties arise, spread and are assimilated. Trends in Genetics 1986;2:159-165.

42. Eickbush TH, Eickbush DG. Finely orchestrated movements: evolution of the ribosomal RNA genes. Genetics 2007; 175:477-485.

43. Zhang X, Eickbush MT, Eickbush TH. Role of recombination in the long-term retention of transposable elements in rRNA gene loci. Genetics 2008;180:1617-1626.

44. Pendás AM, Morán P, Garcia-Vázquez E. Ribosomal RNA genes are insterespersed throughout a heterochromatin chromosome arm in Atlantic salmon. Cytogenet Gen Res 1993;63:128-130.

Address correspondence to: Renata Coelho Rodrigues Noronha, PhD

Laboratório de Citogenética

Centro de Estudos Avançados da Biodiversidade Instituto de Ciências Biológicas Universidade Federal do Pará Belém 66075-110 Para Brazil

E-mail: renatarcrn@gmail.com 